\title{
Modelling reductions of soil erosion and pesticide loads from grain cropping due to improved management practices in the Great Barrier Reef catchments
}

\author{
$\underline{\text { J.S. Owens }}^{\text {a }}$, D.M Silburn ${ }^{\text {b }}$ and D.M. Shaw ${ }^{b}$ \\ ${ }^{a}$ National Centre for Engineering in Agriculture, University of Southern Queensland \\ ${ }^{b}$ Department of Natural Resources and Mines, Queensland \\ Email:jo.owens@usq.edu.au
}

\begin{abstract}
The greatest water quality risks to the Great Barrier Reef are excess nutrients, fine sediments and pesticides contained in terrestrial runoff as these are a major issue affecting the health and resilience of the Great Barrier Reef. In response to a decline in water quality entering the Great Barrier Reef lagoon, the Reef Water Quality Protection Plan (Reef Plan) was developed as a joint Queensland and Australian Government initiative. Reef Plan set water quality improvement targets. Progress towards these targets are assessed through the Paddock to Reef Integrated Monitoring, Modelling and Reporting Program. To help achieve the targets, improvements in land management are being driven by a combination of the Australian Government's reef investments, along with Queensland Government and industry-led initiatives in partnership with regional Natural Resource Management groups.
\end{abstract}

Identifying farm management practices that reduce sediment, nutrient and pesticide runoff loads at a paddock scale is the first step towards improving water quality at the larger catchment scale and subsequently in the Great Barrier Reef lagoon. To model the grains industry, farm management practices for dryland cropping were defined under a water quality risk framework. Practices in the framework primarily affect soil/sediment transport, nutrient and pesticide application practices; and were grouped as Low, Moderate-Low, Moderate and High risk practices. This paper summarises the paddock scale modelling of the effectiveness of improved management practices for reducing off farm losses of sediment, nutrients and pesticides in dryland grain cropping.

Paddock scale agricultural models allow explicit representation of management options available to producers. These include changes in crop rotations, tillage intensity and pesticide and nutrient application timing and rate. Importantly, the ability to simulate management practices on a daily time step means that interactions between the timing of management events and rainfall can be calculated. The results of paddock scale modelling are used in the catchment models to assess the effects of farm scale management decisions on water quality for the whole of the Great Barrier Reef catchment. Key messages from the development and application of the paddock scale modelling for dryland grain cropping in the Great Barrier Reef catchments are:

- Greatest overall reductions in soil erosion can be made by coupling reduced or zero-tillage practices with well-designed controlled traffic farming (CTF) systems.

- Greater than $90 \%$ reduction in soil erosion results from changing management practice from " $\mathrm{D}$ " management scenarios (High risk; full cultivation) to "A" management scenarios (Low risk; zero-till farming with CTF and contour banks).

- Soil erosion is greater in fallows after chickpea, mungbean and sunflower crops than after sorghum and wheat crops. This is due to the small amounts and more rapid decomposition of stubble after chickpea, mungbean and sunflower crops than after sorghum and wheat crops, leaving less cover to protect the soil surface.

- Atrazine runoff loads from cropping land respond directly to both application rate and to time of application relative to runoff. Tillage and traffic systems had a secondary level of effect.

- There was a clear trend of decreasing atrazine runoff load as a percentage of atrazine applied, with the change from D (High risk) to A (Low risk) management scenarios. However, total atrazine loads do not follow this trend because atrazine use increases with A and B management practices. This could be viewed as an outcome of practices that achieve Low risk sediment outcomes (reduced tillage) or the Water Quality Risk Framework could be improved to reduce atrazine use for low risk scenarios.

Keywords: Paddock to Reef, grain, cropping, water balance modelling, HowLeaky 


\section{INTRODUCTION}

Over the past 150 years, Great Barrier Reef catchments have been extensively modified for agricultural production and urban settlement leading to a decline in water quality entering the Great Barrier Reef lagoon (Scientific Consensus Statement, Brodie et al. 2013). In response to these water quality concerns the Reef Water Quality Protection Plan (Reef Plan) 2003 was initiated and updated in 2009 and again in 2013 by a joint Queensland and Australian government initiative. Water quality and management practice targets were outlined for catchments discharging to the Great Barrier Reef, with the goal to ensure that the quality of water entering the Reef has no detrimental impact on the health and resilience of the Reef. A key aspect of the initiative is the Paddock to Reef (P2R) Integrated Monitoring, Modelling and Reporting Program (Carroll et al. 2011). This program measures and reports on progress towards the water quality targets outlined in the Reef Plan in annual Report Cards.

Paddock scale agricultural systems models such as HowLeaky were used to estimate the effects of improved management practices on runoff and loads of sediment, nutrients and pesticides. The results from these paddock scale models, or relationships derived from them, were used in Source Catchment modelling so that effects of management practice changes could be simulated at the catchment scale (McCloskey et al. 2017). Daily time series loads of constituents such as sediment, phosphorus species and pesticides in runoff were supplied from HowLeaky model runs to the Source Catchments models. The key advantage of this modelling approach was the ability to investigate the relative benefits of adopting improved management practices at a paddock scale on end of catchment water quality.

A Water Quality Risk Framework was established by Department of Agriculture and Fisheries and the grains industry (Grains Best Management Practice, www.grainsbmp.com.au). This framework defines various levels of management practice for soil/sediment, nitrogen fertiliser and pesticides (i.e. management combinations) and their qualitative risk to water quality. The quantitative effects of levels of the Water Quality Risk Framework on water quality for the grains industry was modelled using HowLeaky. The HowLeaky model was run for the combinations of key soil, climate and management levels for grain production in all Great Barrier Reef catchments. This paper describes the paddock modelling approach and selected results for dryland cropping in the Great Barrier Reef catchments.

\section{METHOD}

\subsection{Description of the study area}

The study area was the six natural resource management (NRM) regions that make up the Great Barrier Reef catchment (Figure 1); Cape York, Wet Tropics, Mackay Whitsundays, Burdekin, Fitzroy and Burnett-Mary. These catchments cover an area of approximately $424,000 \mathrm{~km}^{2}$ and flow into the Great Barrier Reef lagoon. The Fitzroy Basin is the largest NRM region, covering an area of approximately $142,000 \mathrm{~km}^{2}$. The Great Barrier Reef catchment encompasses dry and wet tropical and subtropical climates. Mean annual rainfall varies from $>6000$ $\mathrm{mm}$ in the ranges of the wet tropics, to $4000 \mathrm{~mm}$ on the coastal plain of the wet tropics, to $<500 \mathrm{~mm}$ in the west of the Burdekin and Fitzroy Basins. Rainfall is strongly seasonal.

Grains cropping in the Great Barrier Reef catchment covers an area of approximately $10,000 \mathrm{~km}^{2}$ (QLUMP Mapping, DSITIA 2012) with crops grown from Cape York to the Burnett-Mary. There are approximately 600 grain growers in the Great Barrier Reef catchments, with the majority in the Central Highlands (Fitzroy) region. Central Queensland is an important graingrowing region producing almost one quarter of all Queensland's cereal grain. Grain production is characterised by a predominance of summer (sorghum) and winter (wheat)

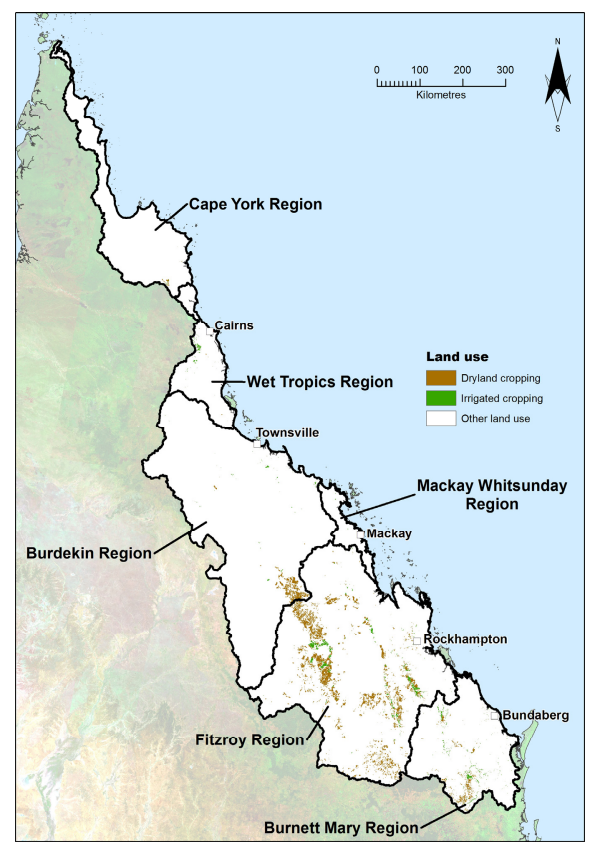

Figure 1. Grain cropping areas in the six natural resource management regions that make up the Great Barrier Reef catchment. cereals. Production of pulses and oilseed crops such as chickpeas, mungbeans and sunflowers is also significant, both in their own right and as break crops to assist weed, pest and disease control in the dominant cereal rotation. 


\subsection{Water quality risk framework for grains}

The Water Quality Risk Framework was developed through the Paddock to Reef program to classify land management options by the risks posed to water quality. Practices are classed as High $(\mathrm{H})$, Moderate (M), Moderate-Low (M-L) and Lowest (L) risk and are referred to as D, C, B and A practices respectively in this paper. Low risk A practices are expected to lead to good water quality whereas high risk D practices are expected to lead to poor water quality. Nitrogen fertilizer management was not considered in the grains Water Quality Risk framework and nitrogen loads in runoff were not modelled. Farming systems were modelled to represent the management practices defined for the Fitzroy region in the water quality risk framework. Improvements in land management practices are reported annually in the Paddock to Reef program. Paddock scale modelling for these improved practices are used in the catchment modelling, and improvements in water quality are reported in the annual Report Cards.

\section{METHOD}

\subsection{Modelling approach}

The HowLeaky model (Rattray et al., 2004; Robinson et al., 2011) was used for modelling grain cropping in the Great Barrier Reef catchments because it has been extensively validated for cropping systems in Queensland. Various studies have validated HowLeaky for runoff, erosion, nutrient movement, pesticide mass balance and runoff, and dissolved and particulate phosphorus in runoff (Shaw and Silburn 2016). Paddock to Reef outputs for Report Card 2015 and 2016 were modelled using the beta version of 5.49.16 of HowLeaky. Model runs were conducted for the period from 1970 to 2015. The 1970 to 1985 period was considered as initializing model conditions (warmup). The results for the 1986 to 2015 period passed to the catchment model.

Soils in the Great Barrier Reef catchment were grouped based on properties considered important for predicting hydrology. Orders of the Australian Soil Classification considered similar in terms of runoff and major physical characteristics were grouped into units called Functional Orders (FO). The soil units within each FO were further classified according to the depth of the A and B horizons and then again by profile permeability. These finer resolution classifications were referred to as 'Soils Groups'. Soil parameters were assigned using the best data available for each soil group and are described in Shaw and Silburn (2016).

Previous report cards for the Paddock to Reef Program modelled four categories of management; A, B, C and D (Shaw and Silburn 2016). For the 2015 and 2016 report cards, the four categories were expanded to 15 management categories in grains to ensure that paddock modelling scenarios aligned with management practice adoption data. Management scenarios were developed with the Fitzroy Basin Association and the Department of Agriculture and Fisheries to ensure that grains paddock modelling scenarios matched Fitzroy Basin Association's investment priorities. These are primarily related to soil management projects. The scenarios considered in the assessment of farm management systems are listed in Table 1. The Fitzroy Basin was the only region with investments in management changes in grains and therefore this region received the most attention.

\subsection{Methodology for modelling one of the Great Barrier Reef Catchments, The Fitzroy Basin}

A landuse layer was intersected with climate and soil to give 36,600 unique combinations to be modelled in the Fitzroy Basin. These were made up of 741 climate files and 114 soils with dryland cropping. These combinations were modelled for all 15 management scenarios in HowLeaky. Because of the size of these files, the Fitzroy catchment had to be broken up into seven sub-catchments to be able to run the HowLeaky model. The most common soil in the Fitzroy Basin was a slowly permeable heavy Vertosol with a shallow A horizon and a deep B horizon (Group 6) which occurred in about $27 \%$ of the grain cropping area. Vertosols made up $80 \%$ of all cropped soils in the Fitzroy.

\section{RESULTS AND DISCUSSION}

The major result of this study are a series of daily runoff, soil erosion, phosphorous and pesticide loads for the different soils and climates over the simulation period for all six natural resource management (NRM) regions in the Great Barrier Reef catchment. In this paper, we present results for one sub-catchment in the Fitzroy Basin, the Nogoa. The results from the Nogoa sub-catchment are generally representative of modelling for all sub-catchments in the Fitzroy as well as the neighbouring regions (Burdekin, Burnett-Mary and the Mackay Whitsundays). In interpreting these data, it is more useful to consider the order of magnitude of loads and relative differences between management scenarios. It is also useful to note that the majority of soils cropped in the Nogoa catchment were Vertosols. 
Owens et al., Modelling reductions of soil erosion and pesticide loads in the Great Barrier Reef catchments

Table 1. Management scenarios modelled in grains cropping for the Fitzroy and neighbouring catchments. Shaded cells indicate scenarios equivalent to the full ABCD definitions with additional scenarios representing intermediate (partial ABCD) management steps.

\begin{tabular}{|c|c|c|c|c|c|c|}
\hline $\begin{array}{c}\text { Scenario Number and } \\
\text { Description }\end{array}$ & $\begin{array}{c}\text { Manage } \\
\text {-ment } \\
\text { Class }\end{array}$ & Tillage & Traffic & $\begin{array}{l}\text { Erosion } \\
\text { Control }\end{array}$ & Crops & Pesticides \\
\hline $\begin{array}{c}1 \\
\text { Forage_CULT_RWT_ICB_Sc1 }\end{array}$ & $\mathrm{D}$ & Cultivation & $\begin{array}{l}\text { Random } \\
\text { Wheel } \\
\text { Traffic }\end{array}$ & $\begin{array}{c}\text { Inadequate } \\
\text { contour banks } \\
\text { constructed }\end{array}$ & $\begin{array}{c}\text { Forage oats, } \\
\text { wheat, forage } \\
\text { sorghum }\end{array}$ & Nil \\
\hline D_Class_CULT_RWT_ICB_Sc2 & $\mathrm{D}$ & Cultivation & $\begin{array}{l}\text { Random } \\
\text { Wheel } \\
\text { Traffic }\end{array}$ & $\begin{array}{c}\text { Inadequate } \\
\text { contour banks } \\
\text { constructed }\end{array}$ & $\begin{array}{l}\text { Sorghum, } \\
\text { Wheat, } \\
\text { Chickpeas }\end{array}$ & $\begin{array}{l}\text { Broadacre spray } \\
\text { for weeds }\end{array}$ \\
\hline D_Class_MT_RWT_ICB_Sc3 & $\mathrm{D}$ & $\begin{array}{l}\text { Minimum } \\
\text { till }\end{array}$ & $\begin{array}{l}\text { Random } \\
\text { Wheel } \\
\text { Traffic }\end{array}$ & $\begin{array}{c}\text { Inadequate } \\
\text { contour banks } \\
\text { constructed }\end{array}$ & As above & $\begin{array}{l}\text { Broadacre spray } \\
\text { for weeds }\end{array}$ \\
\hline $\begin{array}{c}4 \\
\text { D_Class_MT_RWT_ACB_Sc4 }\end{array}$ & $\mathrm{D}$ & $\begin{array}{l}\text { Minimum } \\
\text { till }\end{array}$ & $\begin{array}{l}\text { Random } \\
\text { Wheel } \\
\text { Traffic } \\
\end{array}$ & $\begin{array}{c}\text { Adequate } \\
\text { contour banks } \\
\text { constructed }\end{array}$ & As above & $\begin{array}{l}\text { Broadacre spray } \\
\text { for weeds }\end{array}$ \\
\hline $\begin{array}{c}5 \\
\text { D_Class_MT_PCTF_ICB_Sc5 }\end{array}$ & $\mathrm{D}$ & $\begin{array}{l}\text { Minimum } \\
\text { till }\end{array}$ & $\begin{array}{l}\text { Partially } \\
\text { matched } \\
\text { wheel } \\
\text { traffic }\end{array}$ & $\begin{array}{l}\text { Inadequate } \\
\text { contour banks } \\
\text { constructed }\end{array}$ & As above & $\begin{array}{l}\text { Broadacre spray } \\
\text { for weeds }\end{array}$ \\
\hline $\begin{array}{c}6 \\
\text { C_Class_MT_PCTF_ACB_Sc6 }\end{array}$ & $\mathrm{C}$ & $\begin{array}{l}\text { Minimum } \\
\text { till }\end{array}$ & $\begin{array}{l}\text { Partially } \\
\text { matched } \\
\text { wheel } \\
\text { traffic }\end{array}$ & $\begin{array}{l}\text { Adequate } \\
\text { contour banks } \\
\text { constructed }\end{array}$ & $\begin{array}{l}\text { Sorghum, } \\
\text { Wheat, } \\
\text { Chickpeas }\end{array}$ & $\begin{array}{l}\text { Broadacre spray } \\
\text { for weeds }\end{array}$ \\
\hline C_Class_MT_CTF_ICB_Sc7 & $\mathrm{C}$ & $\begin{array}{l}\text { Minimum } \\
\text { till }\end{array}$ & $\begin{array}{l}\text { Full } \\
\text { Controlled } \\
\text { traffic }\end{array}$ & $\begin{array}{l}\text { Inadequate } \\
\text { contour banks } \\
\text { constructed }\end{array}$ & As above & $\begin{array}{l}\text { Broadacre spray } \\
\text { for weeds }\end{array}$ \\
\hline C_Class_MT_CTF_ACB_Sc8 & $\mathrm{C}$ & $\begin{array}{l}\text { Minimum } \\
\text { till }\end{array}$ & $\begin{array}{l}\text { Full } \\
\text { Controlled } \\
\text { traffic }\end{array}$ & $\begin{array}{c}\text { Adequate } \\
\text { contour banks } \\
\text { constructed }\end{array}$ & As above & $\begin{array}{l}\text { Broadacre spray } \\
\text { for weeds }\end{array}$ \\
\hline $\begin{array}{c}9 \\
\text { C_Class_ZT_RWT_ICB_Sc9 }\end{array}$ & $\mathrm{C}$ & Zero till & $\begin{array}{l}\text { Random } \\
\text { Wheel } \\
\text { Traffic }\end{array}$ & $\begin{array}{l}\text { Inadequate } \\
\text { contour banks } \\
\text { constructed }\end{array}$ & $\begin{array}{l}\text { Sorghum, } \\
\text { Wheat, } \\
\text { Chickpeas, } \\
\text { Mungbeans, } \\
\text { Sunflowers }\end{array}$ & $\begin{array}{l}\text { Broadacre spray } \\
\text { for weeds }\end{array}$ \\
\hline $\begin{array}{c}10 \\
\text { C_Class_ZT_RWT_ACB_Sc10 }\end{array}$ & $\mathrm{C}$ & Zero till & $\begin{array}{l}\text { Random } \\
\text { Wheel } \\
\text { Traffic }\end{array}$ & $\begin{array}{c}\text { Adequate } \\
\text { contour banks } \\
\text { constructed }\end{array}$ & As above & $\begin{array}{l}\text { Broadacre spray } \\
\text { for weeds }\end{array}$ \\
\hline $\begin{array}{c}11 \\
\text { C_Class_ZT_PCTF_ICB_Sc11 }\end{array}$ & $\mathrm{C}$ & Zero till & $\begin{array}{l}\text { Partially } \\
\text { matched } \\
\text { wheel } \\
\text { traffic }\end{array}$ & $\begin{array}{l}\text { Inadequate } \\
\text { contour banks } \\
\text { constructed }\end{array}$ & As above & $\begin{array}{l}\text { Broadacre spray } \\
\text { for weeds }\end{array}$ \\
\hline $\begin{array}{c}12 \\
\text { B_Class_ZT_PCTF_ACB_Sc12 }\end{array}$ & B & Zero till & $\begin{array}{l}\text { Partially } \\
\text { matched } \\
\text { wheel } \\
\text { traffic }\end{array}$ & $\begin{array}{l}\text { Adequate } \\
\text { contour banks } \\
\text { constructed }\end{array}$ & As above & $\begin{array}{l}\text { Broadacre spray } \\
\text { for weeds }\end{array}$ \\
\hline B_Class_ZT_CTF_ICB_Sc13 & B & Zero till & $\begin{array}{l}\text { Full } \\
\text { Controlled } \\
\text { traffic }\end{array}$ & $\begin{array}{l}\text { Inadequate } \\
\text { contour banks } \\
\text { constructed }\end{array}$ & As above & $\begin{array}{l}\text { Broadacre spray } \\
\text { for weeds }\end{array}$ \\
\hline A_Class_ZT_CTF_ACB_Sc14 & A & Zero till & $\begin{array}{l}\text { Full } \\
\text { Controlled } \\
\text { traffic }\end{array}$ & $\begin{array}{l}\text { Adequate } \\
\text { contour banks } \\
\text { constructed }\end{array}$ & $\begin{array}{c}\text { Sorghum, } \\
\text { Wheat, } \\
\text { Chickpeas, } \\
\text { Mungbeans, } \\
\text { Sunflowers, } \\
\text { Maize }\end{array}$ & $\begin{array}{l}\text { Broadacre spray } \\
\text { for weeds }\end{array}$ \\
\hline A_Class_ZT_CTF_ACB_WS_Sc & $\mathrm{A}+$ & Zero till & $\begin{array}{l}\text { Full } \\
\text { Controlled } \\
\text { traffic }\end{array}$ & $\begin{array}{l}\text { Adequate } \\
\text { contour banks } \\
\text { constructed }\end{array}$ & As above & $\begin{array}{l}\text { Site specific } \\
\text { weed control } \\
\text { (weed seeker) }\end{array}$ \\
\hline
\end{tabular}

* RWT - random wheel traffic, PCTF - partially matched wheel traffic, CTF - full control traffic farming, CULT - cultivation, MT minimum tillage, ZT - zero tillage, ACB - adequate contour banks, ICB - inadequate contour banks, WS - weed seeker, Sc - Scenario

Annual average rainfall across the 75 climate locations modelled in the cropping areas of the Nogoa catchment was $610 \mathrm{~mm}$, and ranged from $588 \mathrm{~mm}$ to $712 \mathrm{~mm}$. The average percentage of rainfall lost via runoff was $5.6 \%$ across all simulations, and ranged from 3 to $9 \%$ as an annual average across all managements, soils and climates. When comparing different management scenarios for the major soil in the catchment, the heavy black Vertosol, the largest runoff volumes simulated were for D class management ( $53 \mathrm{~mm} / \mathrm{yr}$ and $8.6 \%$ of rainfall). This was due to the lower frequency of crop planting, which results in rainfall occurring on soil with a higher antecedent moisture content as well as fallows with low cover. Both A and B management classes had lower 
runoff volumes $(\sim 20 \mathrm{~mm} / \mathrm{yr}$ and $3.4 \%$ of rainfall) due to opportunity cropping with higher cropping frequencies, zero tillage practices and controlled traffic farming (CTF), which all enhanced infiltration. The runoff amounts simulated were lower than estimates from field sites in the Fitzroy region. Observed runoff from grain cropping at the Brigalow Catchment Study was $72 \mathrm{~mm} / \mathrm{yr}$ (11\% of rainfall) from 1984-2004 (Thornton et al., 2007). The Moonggoo site at Capella (Murphy et al. 2013) which also had about 11\% of rainfall running off over the study period (2000 to 2008). This difference is primarily due to higher crop frequencies and differences in management modelled compared to the runoff studies.

Management scenarios with CTF, zero tillage and high crop frequency have lower runoff compared to some of the $\mathrm{C}$ and $\mathrm{D}$ scenarios with random wheel traffic, full cultivation and lower crop frequency. A key finding of this study was that lower runoff on CTF and partial CTF management practices often resulted in higher crop frequencies, and caused a spiral effect of further reducing runoff (equally increasing rainfall use efficiency) and pollutant loads.

Erosion rates followed a similar pattern to runoff, because of the strong link of runoff and soil loss, and the effects of cover on both. Soil erosion was lower in A management scenarios and higher in D management scenarios, with greater than $90 \%$ reduction in erosion between full cultivation vs. zero till with contour banks. Management scenarios with partial and full CTF had lower erosion, because of reduced runoff. Management scenarios with adequate contour banks (ACB) had lower soil erosion (Figure 2). Modelled soil erosion ranged from 0.5 to $15 \mathrm{t} / \mathrm{ha} / \mathrm{yr}$ and averaged around $5 \mathrm{t} / \mathrm{ha} / \mathrm{yr}$ across all management, soil and climate scenarios in the Nogoa Catchment. These losses represent the soil eroded and do not include any correction for deposition between the site of erosion and losses from a paddock to stream (i.e. the delivery ratio). For the Paddock to Reef program, sediment delivery ratios are applied in the catchment scale models.

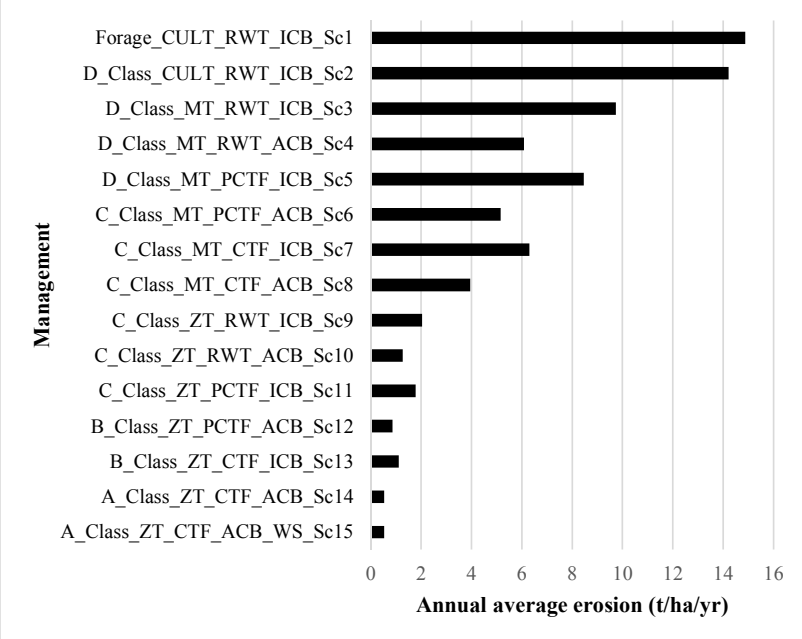

Figure 2. Average annual soil erosion in the Nogoa catchment (Fitzroy Basin), for management scenarios ranging from A with control traffic farming and adequate contour banks to D (full cultivation with inadequate contour banks).

Crop frequency had a large impact on soil

erosion, although it is difficult to separate out the effect of crop frequency from all of the practices that change between D and A management scenarios. Crop frequency affects which crops are selected for sowing in the model (winter/summer) and how often crops are grown. In this region with higher summer rainfall, planting winter crops and having bare fallows over the summer provides conditions for high runoff and soil loss. High risk (D) management scenarios were represented by less frequent planting than in other management scenarios and conventional tillage practices that resulted in reduced crop and residue cover. Annual average soil erosion was greatest from the D management scenarios $(14 \mathrm{t} / \mathrm{ha} / \mathrm{yr})$. Both $\mathrm{A}$ and B scenarios, with more frequent planting, zero tillage practices and CTF produced low amounts of soil erosion ( 0.5 and $1.0 \mathrm{t} / \mathrm{ha} / \mathrm{yr})$. The largest benefit in terms of prevention of erosion was through the change from a $\mathrm{D}$ to an A management scenarios. This resulted in a 95\% reduction in annual average soil loss.

The effects of management practices varied between soil-climate combinations. Sites with higher rainfall had higher runoff and soil erosion. The soil type with the highest soil erosion were the Sodosols, the same soil with the highest runoff. Soil erosion is greater in fallows after chickpea, mungbean and sunflower crops than after sorghum and wheat crops. This is due to the small amounts and more rapid decomposition of stubble after chickpea, mungbean and sunflower crops than after sorghum and wheat crops, leaving less cover to protect the soil surface. Longer lasting cover from sorghum and wheat crops protects the soil from runoff and subsequent soil erosion and pesticide movement off farm.

Atrazine was the only pesticide reported in the Reef Report Card from grain cropping areas. It is the only reef priority Photosystem-II (PSII) inhibiting herbicide commonly applied to crops in the Fitzroy. The annual PSII pesticide loads from the management scenarios was highly variable since atrazine was only applied to sorghum and maize crops, which were not planted each year. Total atrazine loads (dissolved and particulate) in the Nogoa catchment ranged from $0 \mathrm{~g} /$ ha to $6 \mathrm{~g} /$ ha (Figure 3). More atrazine was lost in C and D scenarios (as a 
percentage of applied) because of higher runoff in these scenarios. Thus, the tillage and cropping management practices (e.g. slightly reduced sorghum plantings) defined under the Water Quality Risk Framework achieve reductions in atrazine losses as a percentage of applied (Figure 3). Atrazine loss was predominantly in the water phase as expected given that atrazine is not strongly sorbed to soil/sediment. Losses in sediment phase ranged from 0 to $0.3 \mathrm{~g} / \mathrm{ha}$ which represented a small proportion of total loss.
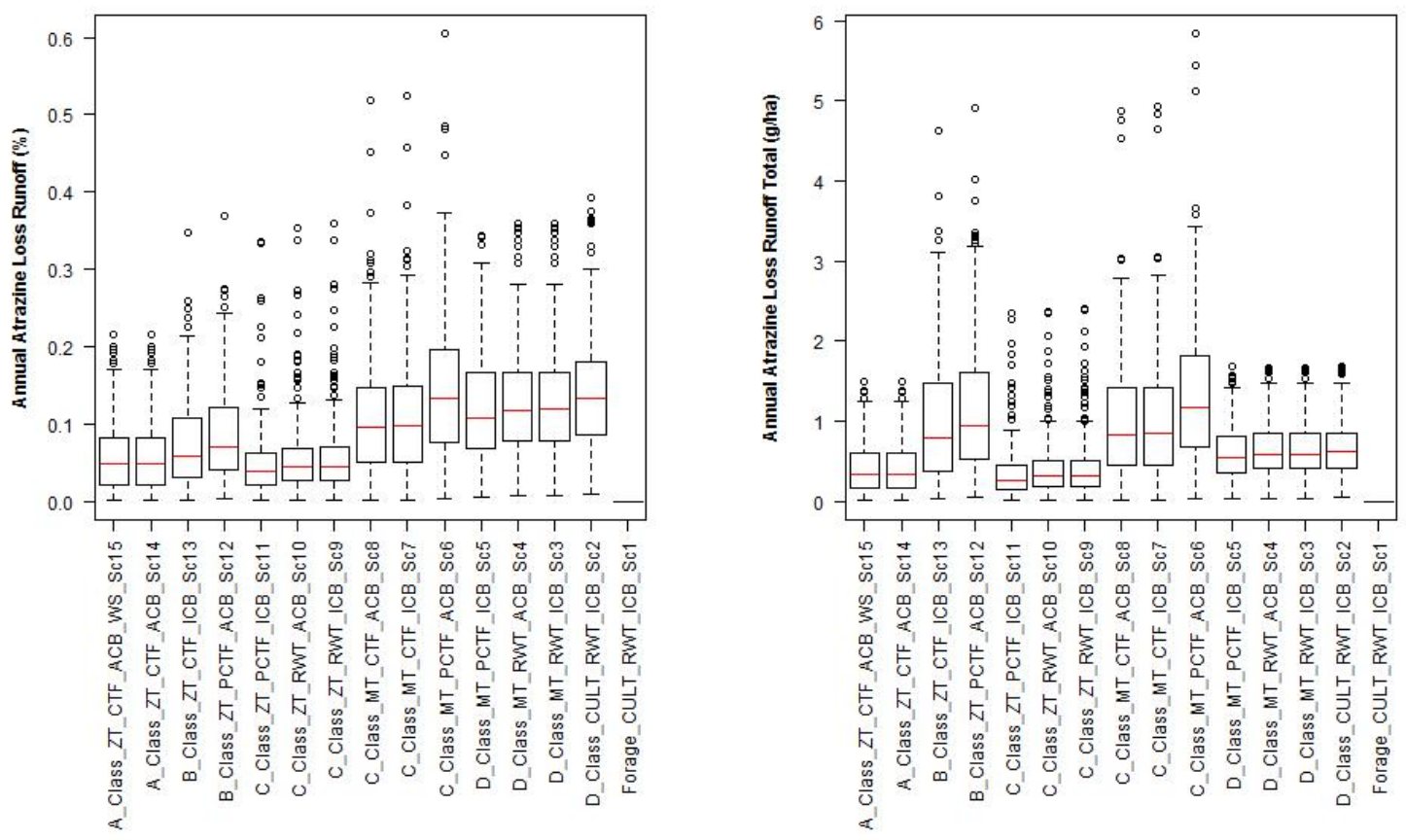

Figure 3. Annual atrazine lost in runoff as (a) percentage of applied, and (b) total dissolved and particulate loads for management scenarios, showing the distribution between soils and climates in the Nogoa catchment.

The magnitude of the loss of atrazine is highly dependent on the timing of the application relative to the following runoff event and the crop residues retained on the paddock from the previous crop. Single storms soon after pesticide application can cause the majority of the annual load (Murphy et al. 2013). Daily loads of atrazine in runoff for the major soil in the catchment (heavy Vertosol) near Capella in central Queensland can be as high as $10 \mathrm{~g} /$ ha for a single event. However, the long-term annual average loads (Figure 3) are much lower because such events (soon after atrazine application) do not occur in most years. Murphy et al. (2013) measured loads of metolachlor of 139 g.a.i/ha or $9.6 \%$ of applied in a wetter than average year near Capella. However, when this is averaged out with many dryer years, years when runoff did not occur within a month of application and years with no atrazine applied, the long-term average loads will be much lower. Rattray et al. (2007) measured a load of 14.2 g.a.i/ha of atrazine in runoff ( $0.4 \%$ of applied) on the Darling Downs. Again runoff in that year was with greater than average (28\% of rainfall or more than twice the expected average). Thus, comparison of long-term model results with short periods of measured data is deceptive and detailed modelling of the particular site and period is needed.

Another source of data which can be compared to the modeling are the loads of atrazine measured in the Fitzroy River. To make this comparison, daily modelled atrazine runoff loads for all the area mapped as grains cropping within a catchment were aggregated to sub-catchments and input into the Source Catchments model (McCloskey et al. 2017). Source Catchments routes these pollutants to the end of catchment. The sum of all atrazine loads from the Source Catchments model for the Fitzroy River shows a good comparison against monitoring data at the end of catchment at Rockhampton (Figure 4). The measured atrazine loads would come from sorghum and maize crops planted in the Fitzroy catchment. The modelled loads represent the annual variation in atrazine load well. The modelling tracks some of the trends year by year even though we are not able to specify the areas planted to sorghum and maize each year (due to lack of such data). Annual variation in runoff (leading to atrazine losses) appears to outweigh variation in the areas planted to sorghum and maize to some extent. 


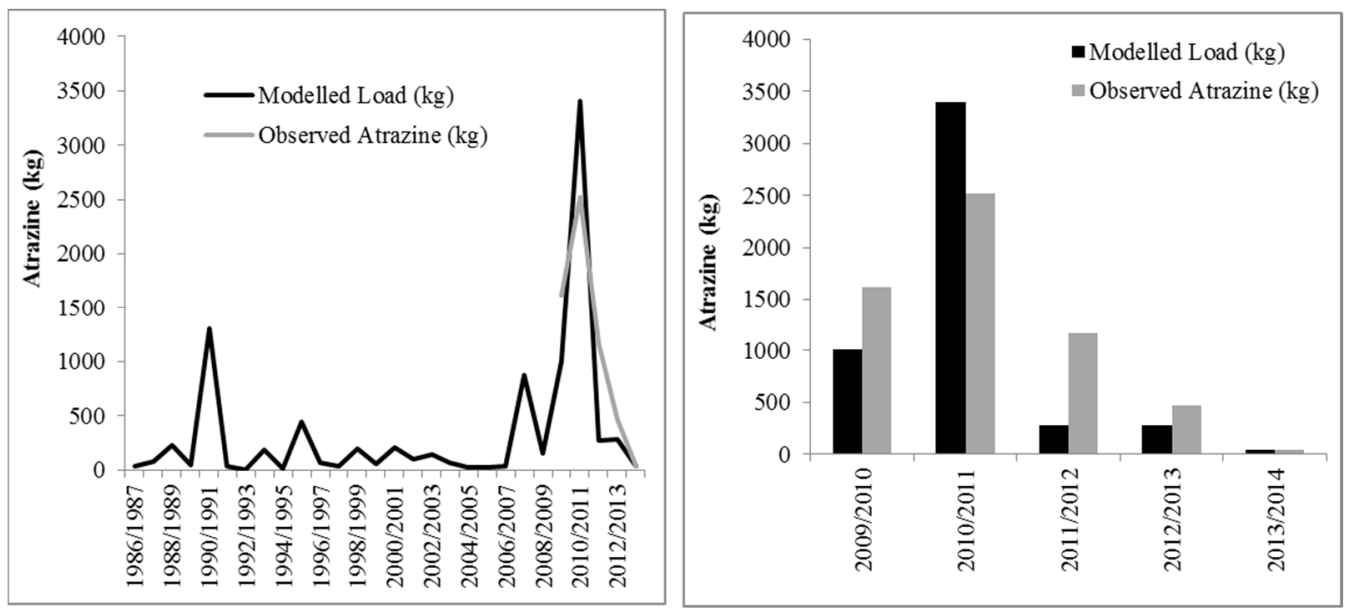

Figure 4. Atrazine loads compared year-by-year (Fitzroy River at Rockhampton) provides validation of paddock modelling at catchment model scale for Report Card 2014 (Source: Shawn Darr, DNRM)

\section{CONCLUSION}

The paddock scale modelling indicates that there is a large potential to manage water quality, particularly from sediment, resulting from dryland grain cropping. The linking of paddock scale models such as HowLeaky with the Source catchment scale model has been shown to provide an effective approach for assessing impacts of the adoption of improved land management practices in the Paddock to Reef Program. Paddock modelling also provides a tool for investigation of management options at a paddock scale which will serve to improve water quality entering the Great Barrier Reef.

\section{ACKNOWLEDGMENTS}

We acknowledge the Australian and Queensland governments as principal investors of the Paddock to Reef program.

\section{REFERENCES}

Carroll, C., Waters, D., Vardy, S., Silburn, D.M., Attard, S., Thorburn, P,J., Davis, A.M., Halpin, N., Schmidt, M., Wilson, B., and Clark, A. (2012). A Paddock to reef monitoring and modelling framework for the Great Barrier Reef: Paddock and catchment component. Marine Pollution Bulletin 65, 136-149.

McCloskey, G.L., Waters. D., Baheerathan, R., Darr, S., Dougall, C., Ellis, R., Fentie, B., Hateley, L. (2017). Modelling pollutant load changes due to improved management practices in the Great Barrier Reef catchments: updated methodology and results - Technical Report for Reef Report Cards 2015, Queensland Department of Natural Resources and Mines, Brisbane, Queensland.

Murphy, T., Dougall, C., Burger, P., Carroll, C. (2013). Runoff water quality from dryland cropping on Vertisols in Central Queensland, Australia. Agriculture, Ecosystems and Environment 180, 21-28.

Rattray, D.J., Freebairn, D.M., McClymont, D., Silburn, D.M., Owens, J., Robinson, B. (2004). HOWLEAKY? The journey to demystifying 'simple' technology. Paper 422. In ISCO 2004 'Conserving Soil and Water for Society: Sharing Solutions', 13th International Soil Conservation Organisation Conference, Brisbane.

Rattray, D.J., Standley, J., Silburn, D.M., Freebairn, D.M., Spann, K.P. (2007). Atrazine degradation and transport in runoff on a black vertisol. Aust. J. Soil Res. 45, 598-606.

Robinson, J.B., Shaw, M., Silburn, D.M., Roberts, A., Viagak, O., McClymont, D. (2011). An improved model for linking Phosphorus loads in runoff to climate, soil and agricultural management. 19th International Congress on Modelling and Simulation, Perth, Western Australia.

Shaw, M., Silburn, M. (Eds.) (2016). Modelling reductions of pollutant loads due to improved management practices in the Great Barrier Reef catchments - Paddock Scale Modelling, Technical Report, Report Cards 2010 to 2013, Queensland Department of Natural Resources and Mines, Brisbane, Queensland

Thornton, C.M., Cowie, B., Freebairn, D., Playford, C. (2007). The Brigalow Catchment Study: II. Clearing brigalow (Acacia harpophylla) for cropping or pasture increases runoff, Aust. J. Soil Res 45, 496-511. 